DATE: June 24,1987

SUBJECT: Status Report on SWSA 6 Geophysical Studies.

TO: T. E. Hyrick

FROM: $\quad$ R. B. Ureier

This report hes been reproduced directly from the best avallable copy.

Avallable to DOE and DOE contractors from the Otfice of Scientific and Technt cal information, P.Q. Box 62, Oak Ridge, TN 37831; prices avallable from (615) 576-8401, FTS 626-8401.

Available to the public from the National Technical Information Service, U.S. Department of Commerce, 5285 Port Royal Rd., Springfield, VA 22181.

NTIS price codes-Printed Copy: A10 Microfiche AO1

This report was prepared as an account of work sponsored by an aguncy of the United 3tates Government. Nelther the United States Government nor any agency thereof, nor any of their employees, makes any warranty, express or implied, or assumes any legal liability or responsibilty for the accuracy, completeness, or usefulness of any information, apparatus, product, or process disclosed, or represents that its use would not infringe privately owned rights. Reference herein to any specific commercial product, process, or service by trade name, tredemark, manufacturer, or otherwise, dose not necessarily constitute or imply its endorsement, recommendation, or favoring by the United States Government or any agency thereof. The views and opinions of authors expressed herein do not necessarily state or reflect those of the United States Government or any agency thereof. 
ORNL/RAP/LTR-87/31

\title{
STATUS REPORT ON SWSA 6 GEOPHYSICAL STUDIES
}

\author{
R. B. Dreier, R. J. Selfridge, and C. M Beaudoin
}

JUNE 1987

\author{
Prepared by the \\ Oak Ridge National Laboratory \\ Oak Ridge, Tennessee 37831 \\ Operated by \\ Martin Marietta Energy Systems, Inc. \\ For the \\ U. S. DEPARTMENT OF ENERGY \\ Under Contract DE-AC05-840R21400
}

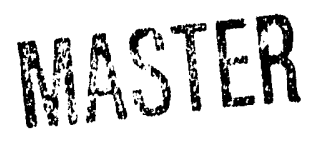




\begin{abstract}
As part of the SWSA 6 remedial investigation activities, surface seismic refraction surveys will be conducted to characterize the thickness of the soil/saprolite horizon. This report presents (1) the project design, (2) results of a feasibility study conducted to assess the suitability of seismic refraction techniques to investigate soil thickness, and (3) a synthesis of existing well construction data that will aid in interpreting results of the geophysical investigations.
\end{abstract}




\section{INTRODUCTION}

As part of the Solid Waste Storage Area (SWSA) 6 remedial investigation activities, surface seismic refraction surveys will be conducted to characterize the thickness of the soil/saprolite horizon (Boegly et al. 1985). The primary advantage of the seismic method is the ability to detect sudden changes in bedrock topography in regions with insufficient borehole data. The lateral resolution capability offered by the seismic refraction method is highly desirable to properly characterize the thickness of the soil/saprolite horizon. This progress report presents a project design for this activity and documents investigations that have been accomplished to complete the project. Data acquisition is expected to be completed during FY-87. 


\section{2. $A P P R O A C H$}

Data acquisition and interpretation will be conducted by Tennessee Valley Authority (TVA) staff under an existing geophysics subcontract with TVA, in cooperation with ORNL staff (primarily R. J. Selfridge, R. O. Kennard, and R. B. Dreier).

The surveys will be conducted using standard shallow seismic refraction techniques (Mooney 1984) with the following exceptions. Each transect will be $480 \mathrm{ft}$ long with 24 geophones spaced $20 \mathrm{ft}$ apart along the transect. A Betsy 8-gauge seisgun source will be used as an energy source. Each transect will have seven energy source locations, 1 at the transect center, 1 at each transect end, and 2 offset at 50-ft increments from each end of the transect. The data will be recorded on a 24-channel I/O seismic recorder that will produce a visual field copy of the seismic traces. The data will be recorded in analog SEG Y format on magnetic tape.

To avoid possible environmental problems resulting from leaving 3-oz. lead slugs in the ground, the seismic source has been slightly modified from normal operating procedures. A one-ft-deep hole will be hand dug and a steel plate (with an attached chain for retrieval purposes) will be placed within the hole. The hole will then be filled with water (tamped) to provide improved energy coupling with the subsurface. The seisgun will be placed over the hole and the slug fired onto the steel plate. The lead slug fully deforms upon impact with the steel plate, thus enssuring that the slug cannot ricochet. The seisgun is removed from its position over the hole and the lead slug and steel plate are retrieved. The subcontractor will be required to collect and account for each shell that is used in the field.

Proposed transect locations (Fig. 1) were chosen to investigate lateral variations in soil/saprolite thicknesses, which are expected to be a function of soil type, bedrock geology, and topography. Hence, transects were located to achieve representative northsouth and east-west transects that sample these different technical parameters (Lietzke and Lee 1986; Dreier et al. 1987). Logistical considerations include: (1) providing easy access for an instrumented vehicle, (2) avoiding an immediate burial trench area for shotpoint locations, and (3) optimizing areal coverage with a minimum number of individual and short transects. In addition, an attempt was made to locate transects near existing wells that were accurately logged during construction. Appropriate borehole data will be used to calibrate and interpret the geophysical data and are discussed in Section 4.

After the field data have been acquired, the records will be processed to produce (1) time/distance plots and (2) top-of-rock plots. In addition, a refraction station summary will be included for each transect. 


\section{FEASIBILITY STUDY}

In order to assess the design and the likelihood of succeeding at conducting a shallow seismic refraction study in SWSA 6, a feasibility study, consisting of two short transects, was conducted by R. A. Hopkins (TVA) and R. J. Selfridge (1A-1G and 2A-2G in Fig. 1). Each transect was $480 \mathrm{ft}$ long with 24 geophones spaced $20 \mathrm{ft}$ apart along the transect. A Betsy 8-gauge Seisgun Source was used as an energy source. Each transect had 9 energy source locations, 1 at the transect center, 1 at each transect end, and 2 offset at 50 -ft increments off each end of the transect. For this feasibility study, an additional two shots were completed at quarter distances along the geophone array to achieve enhanced acoustic velocity control. Unless required, these two additional shots will not be used for the final survey. The data were recorded on a 24 channel $1 / O$ seismic recorder that produced a field copy of the seismic traces. The data were also recorded in analog SEG Y format on magnetic tape for use in future data processing and for long-term data storage.

Preliminary results of the study are shown in the following figures:

Fig. 2 (seismic refraction time/distance plot - 1A-1G)

Fig. 3 (seismic refraction top-of-rock plot 1A-1G)

Fig. 4 (seismic refraction time/distance plot $-2 A-2 G$ )

Fig. 5 (seismic refraction top-of-rock plot $2 \mathrm{~A}-2 \mathrm{G}$ )

In addition, summaries of the field data and processing assumptions necessary to generate the time/distance and top-of-rock plots are presented in Appendix A. Of the assumptions, the most significant is the estimation of $1000 \mathrm{ft} / \mathrm{sec}$ for the soil/saprolite (overburden) acoustic velocity. Such an assumption was necessary because well construction records that provided depth-to-bedrock information were not available at the time of the seismic data processing. Hence, the study could not be calibrated to match existing site-specific conditions at SWSA 6.

Uncertainties created by soil velocity assumptions can be minimized by using well construction records. The seismic refraction data can be calibrated by matching depth to top of rock predicted from seismic records with depth to top of bedrock determined by an accurate well construction record. Using this depth information together with seismic travel-time information, an accurate acoustic velocity for the soil/saprolite can be derived. This velocity will then be used to process the bulk of the refraction data acquired for the final phase of the project. Data quality can easily be evaluated by comparing the postcalibration seismic refraction top of rock plots (analogous to Figs. 3 and 5) with appropriate well construction records for wells located near the survey transects. Further comparisons of well records and seismic data are presented in Section 5. 


\section{EXISTING WELL CONSTRUCTION RECORDS}

As part of geologic and hydrologic investigations in SWSA 6, numerous boreholes have been constructed in this waste facility (Dreier,1986; and unpublished well records).

Borehole locations with accompanying well names are shown in Figs. 6 and 7. The quality of the construction records varies considerably, from no information to detailed logs required by regulatory agencies. Examination of construction records allows estimation of depth to bedrock at the well site. Relevant construction information includes (1) depth of split-spoon refusal; (2) depth of auger refusal (this depth can vary as a function of the auger diameter); (3) logged color or rock change; and (4) depth of conductor casing. For the purposes of this study, construction information was divided into two types that generally should distinguish different depth horizons:

(1) split-spoon refusal, large diameter (>12") auger refusal, and a "shallow" color or rock change; or

(2) depth of conductor casing, and depth of small diameter (<12") auger refusal.

Type 1 and Type 2 information are plotted and contoured in Figs. 6 and 7 respectively. Type 1 data distinguish a shallow horizon that is possibly undetected by seismic refraction techniques. The depth to this interval ranges from 1 to $25 \mathrm{ft}$. In general, the greatest soil/saprolite thicknesses are preserved on topographic highs, such as on the southern and western hills (Fig. 8). In addition, stream banks in the northern section of the facility show increased soil/saprolite thicknesses. The asymmetry of the contours about this stream valley may be an artifact of data that is derived from different drilling methods. For example, the 19.5-ft depth listed for well HHMS-7 reflects a minimum depth, and this portion of the well was not drilled to auger refusal.

Type 2 data distinguish a horizon that most likely shows a greater contrast in acoustic properties. Hence, this horizon has a greater probability of being detected by seismic techniques. Thickness trends for Type 2 data roughly match those of Type 1 except for the north trending drainage area in the eastern portion of SWSA 6. In this area, Fig. 8 shows a decrease in thickness, whereas Fig. 9 shows an increase in thickness. Again, this may result from the quality and location of the well data points. The increased thickness (Fig. 9) may actually reflect thickness values for the stream valley walls rather than values for the stream floor, which may be thinned similarly to that observed in Fig. 8. Available data cannot resolve this discrepancy. 


\section{DISCUSSION}

Comparison of results of the feasibility study with well construction records shows a good correlation for transect $2 \mathrm{~A}-2 \mathrm{G}$. Areas of greatest mismatch, primarily at the southern end of the transect, near stations $4+10-5+30$, correspond to areas that are poorly constrained by construction records. Results for transect $1 \mathrm{~A}-1 \mathrm{G}$ are less satisfactory. This transect was purposely located over a waste trench region to determine the effect of trenches on the seismic data. On review of the seismic field records, and a SWSA 6 trench location map, the following geophones were located over waste trenches.

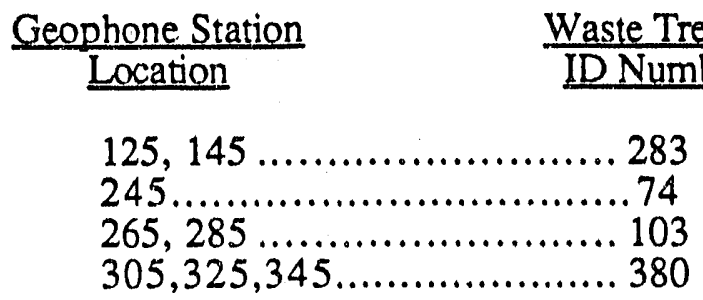

Geophone station locations $1+25$ and $1+45$ on transect $1 \mathrm{~A}-1 \mathrm{G}$ may or may not have been located over trenches. Only an approximate location of the geophysical transect could be determined from field notes because survey flags identifying the transect locations were destroyed or removed before station locations could be accurately surveyed.

Fill materials in the trenches have substantially delayed acoustic velocities in comparison with the undisturbed, consolidated material surrounding the trenches. The time/distance plot for transect 1 A-1G (Fig. 2) graphically displays this sudden change in acoustic velocity due to the presence of waste trenches. Unrecognized velocity changes result in erroneous depth to bedrock calculations, such as are shown for area B in Fig. 3 where delayed acoustic velocities are mistakenly translated into increased thicknesses.

The seismic data show a decrease in soil/saprolite thickness (interval A in Fig. 3) that was not detected from existing well construction records. As stated above, station locations that correspond to interval $\mathrm{A}(1+25$ and $1+45)$ are poorly constrained, and it cannot be determined if they are located over Trench 283 . The seismic data, however, indicate that the geophones at stations $1+25$ and $1+45$ were not intersecting seismic waves that traveled through Trench 283 , because the recorded travel time was not delayed by slower trench-fill acoustic velocities (Fig. 2). The increase in clevation of the top-of-rock plot at interval A would therefore indicate a slight rise in the bedrock topography.

The feasibility study indicates that seismic refractions methods work well in the SWSA 6 area and that a good correlation exists between quality well construction records and seismic results. The capability of this method to quickly and inexpensively (in comparison to well drilling) determine overburden thickness is highly desirable for the SWSA 6 investigation. To ensure data quality, each end of the geophone lines should be surveyed immediately after the seismic field work is completed. In addition, the number of geophone spreads located over the top of waste trenches should be minimized, and data collected from geophones located over waste trenches should be marked for proper data calibration and interpretation. 


\section{REFERENCES}

W. J. Boegly Jr., R. B. Dreier, D. D. Huff, A.D. Kelmers, D. C. Kocher, S. Y. Lee, F. R. O'Donnell, F. G. Pin, and E. D. Smith, 1985. Characterization Plan for Solid Waste Storage Area 6, ORNL/TM-9877.

R. B. Dreier, 1986. Hydrostatic Head Monitoring Stations: Summary of Well Construction of GPP 84 (Pits and Trenches) and GPP 85 (SWSA G) Well Clusters, ORNL/RAP/LTR-86/87.

R. B. Dreier, C. S. Haase, C. M. Beaudoin, H. L. King, and J. Switek, 1987. Summary of Geological Data in the Vicinity of the Hydrofracture Facilities, ORNL/RAP/LTR-87/26.

D. A. Lietzke, and S. Y. Lee, 1986. Soil Survey of Solid Waste Storage Area 6, ORNL/TM-10013.

H. M. Mooney, 1984. Handbook of Engineering Geophysics, Volume 1: Seismic. Bison Instrument Inc., Minneapolis, MN, $195 \mathrm{pp}$. 


\section{FIGURE CAPTIONS}

Fig. 1. Location map of the proposed seismic refraction transects and of the feasibility study transects. Because the regional strike trends approximately grid east, the proposed north-south trending transects will sample different geologic lithologies (sections of the Maryville Limestone and the Nolichucky Shale of the Conasauga Group). In addition all transects are located over a variety of soil types and topographic expressions. The feasibility study (transects 1A-1G and 2A-2G) is discussed in Sections 3 and 5, and results of the study are graphically represented in Figs. 2-5.

Fig. 2. Seismic refraction time/distance plot for transect $1 \mathrm{~A}-1 \mathrm{G}$. The stations are $20 \mathrm{ft}$ apart and show geophone locations. Asterisk markers represent the travel time of the seismic wave from source $1 \mathrm{~A}$ to the given station. Open triangle markers represent the travel time of the seismic wave from source $1 \mathrm{G}$ to the given station. Forward (or reverse) velocities are a function of the slope of a best fit line through the given travel times. These velocities would be equal if the topography and the bedrock surface were flat and if the wave traveled through a homogeneous medium. Seismic velocity changes in the medium cause the local poor linear fit, which, in this case, is attributed to the presence of trenches that show slower seismic velocities.

Fig. 3. Top-of-rock-plot for transect 1A-1G. The figure shows a profile from 1A to $1 \mathrm{G}$ that includes surface elevation (open box), top of rock estimated by seismic refraction methods (upside down T), and top of rock estimated from well construction records (dashed line). Markers for surface elevation and seismic top of rock are placed at each station (geophone location). Surface elevations at each station were estimated from topographic maps and have not been rechecked by surveying methods. Transect $1 \mathrm{~A}-1 \mathrm{G}$ is located over several trenches (Fig. 1), and the abrupt break (or pull-down) at pts. A and B results from slower acoustic velocities within the trenches.

Fig. 4. Seismic refraction time/distance plot for transect $2 \mathrm{~A}-2 \mathrm{G}$. The stations are $20 \mathrm{ft}$ apart and show geophone locations. Asterisk markers represent the travel time of the seismic wave from source $2 \mathrm{~A}$ to the given station. Open triangle markers represent the travel time of the seismic wave from source $2 \mathrm{G}$ to the given station.

Fig. 5. Top-of-rock plot for transect $2 \mathrm{~A}-2 \mathrm{G}$. The figure shows a profile from $2 \mathrm{~A}$ to $2 \mathrm{G}$ that includes surface elevation (open box), top of rock estimated by seismic refraction methods (upside down T), and top of rock estimated from well construction records (dashed line). Markers for surface elevation and seismic top of rock are placed at each station (geophone location). Surface elevations at each station were estimated from topographic maps and have not been rechecked by surveying methods.

Fig. 6. SW'SA 6 Soil isopach map - Data Type 1. This map shows the depth to a shallow soil horizon that is defined by: (1) split-spoon refusal; (2) large diameter $\left(>12^{\prime \prime}\right)$ auger refusal; and (3) a "shallow" color or rock change. See text for discussion.

Fig. 7. SWSA 6 Soil isopach map - Data Type 2. This map shows the depth to bedrock, which is defined by (1) depth of conductor casing; and (2) depth of small diameter (<12") auger refusal. See text for discussion. 


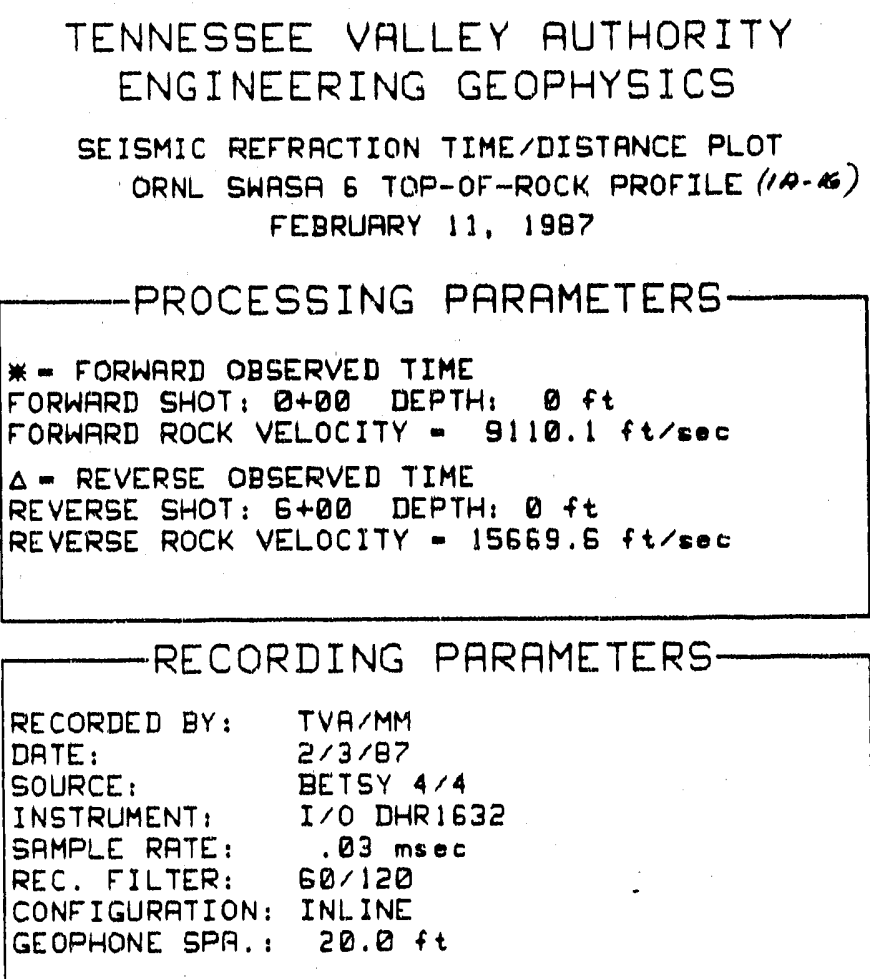

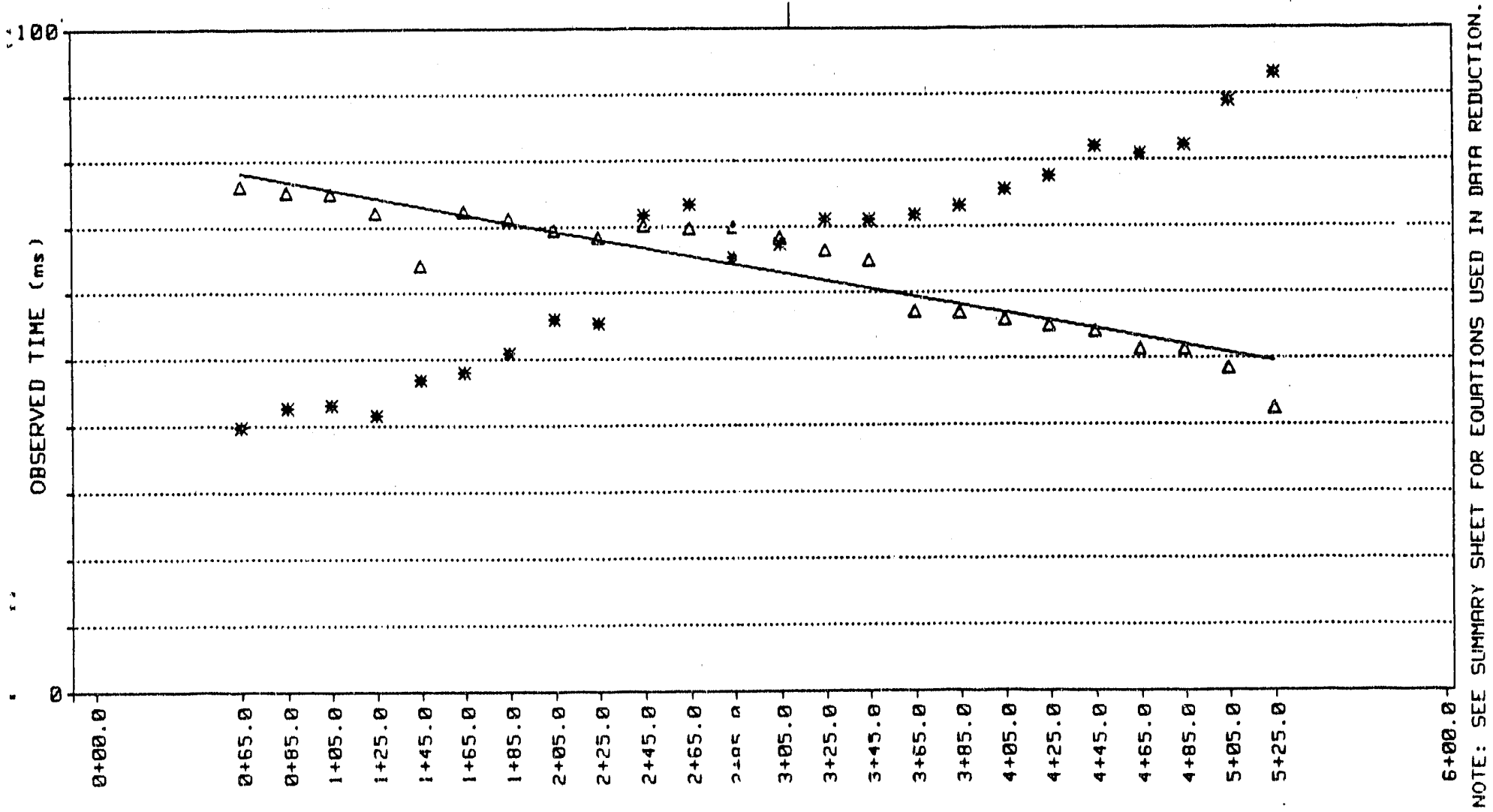


Figure 3

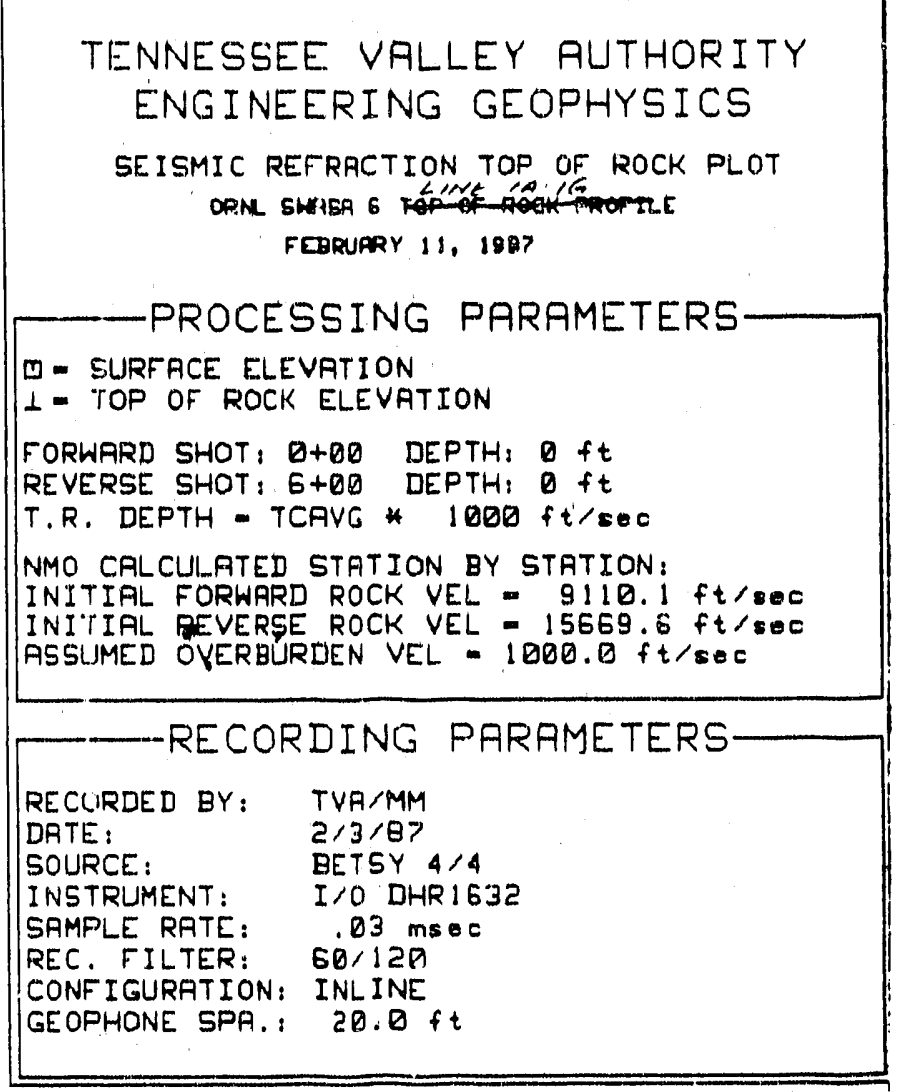

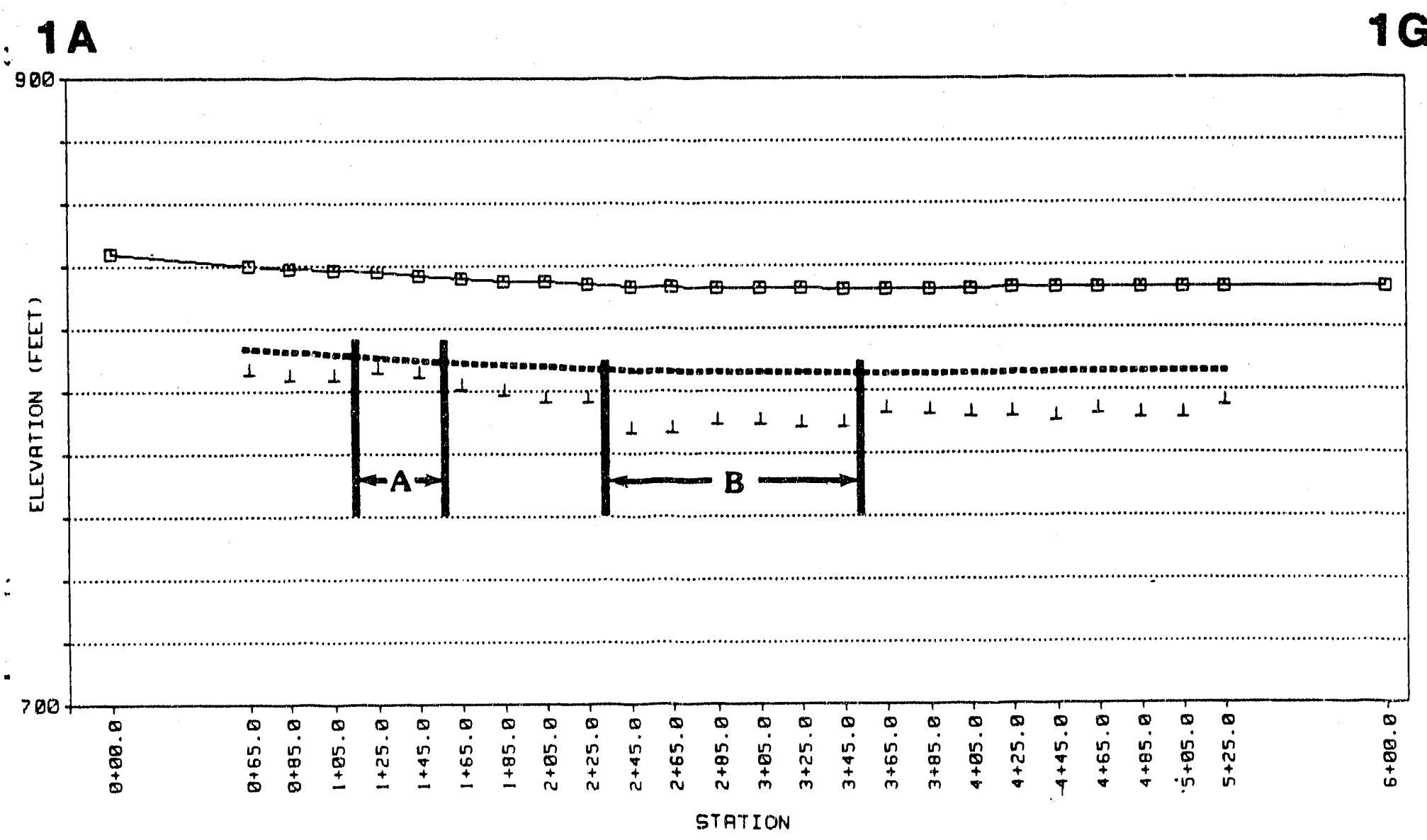


TENNESSEE VALLEY RUTHORITY

ENGINEERING GEOPHYSICS

SEISMIC REFRACTION TIME/DISTANCE PLOT

ORNL SWASA 6 LINE 2A-2G

FEBRUARY 12,1987

PROCESSING PARAMETERS

* FORWARD OBSERVED TIME

FORWARD SHOT: $\theta+D B$ DEPTH: $B \mathrm{ft}$

FORWRRE ROCK VELOCITY - $8653.9 \mathrm{ft} / \mathrm{sec}$

$\triangle$ = REVERSE OBSERVED TIME

REVERSE SHOT: $5+95$ DEPTH: $0 \mathrm{ft}^{\circ}$

REVERSE ROCK VELOCITY - $15750.2 \mathrm{f} t / \mathrm{soc}$

RECORDING PRRAMETERS-

RECORDED BY: TVA MMM

DATE:

SOURCE:

INSTRUMENT: I/O DHRIE32

SAMPLE RATE: $.03 \mathrm{~ms} \in \mathrm{C}$

REC. FILTER: 60.120

CONF I GURATION: INL INE

GEOPHONE SPA.: $20.0 \mathrm{ft}$

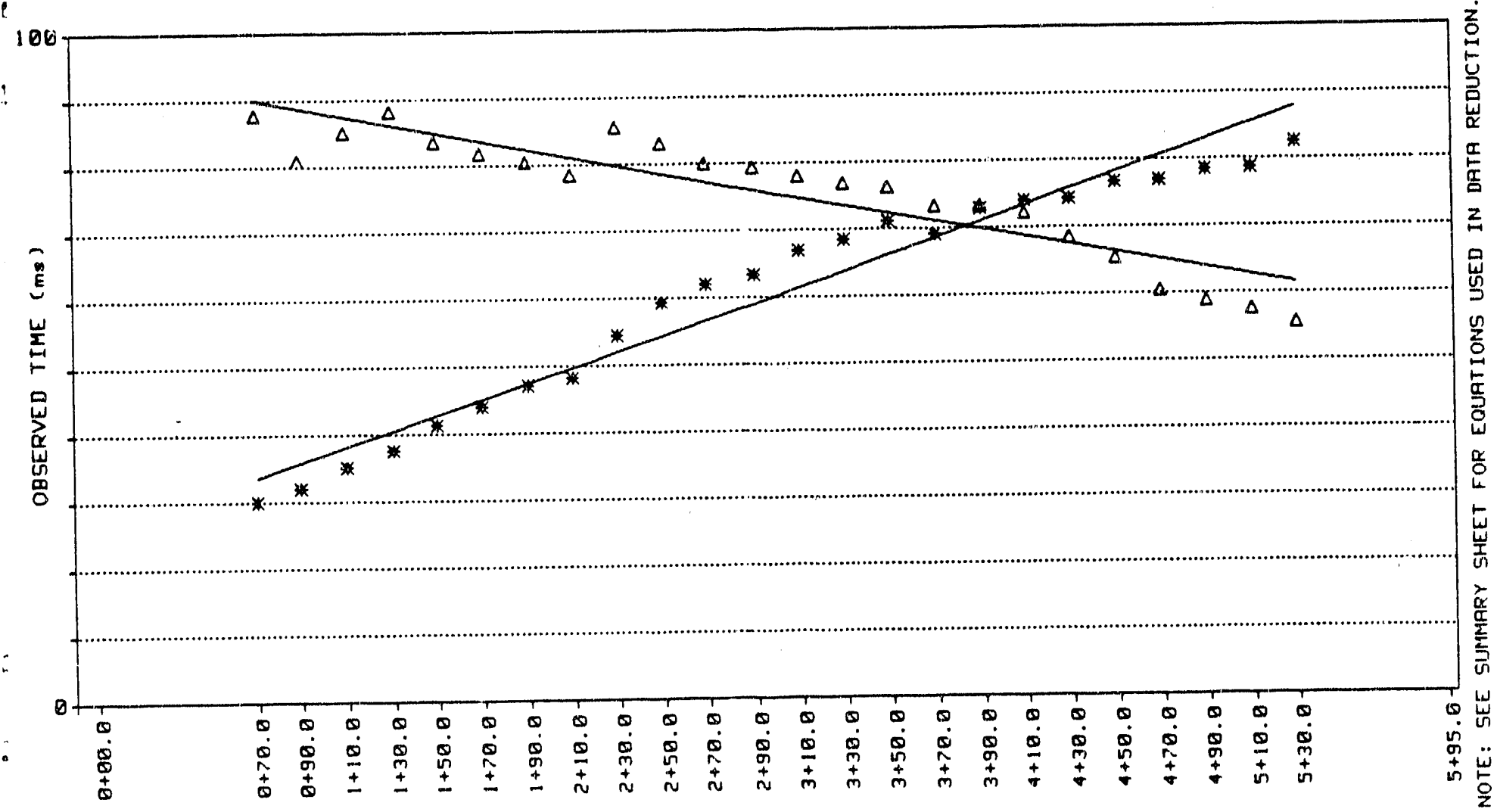

STATION 
Figure 5

ORNL SWASA 6 LINE PA-2G

FEBRUARY 12, 198?

T.R. DEPTH - TCAVE * $10004 t / 800$

NMO CALCULRTED STRTION BY STATION:

INITIRL FORWRRE ROCK VEL $=8663 . \mathrm{g} \mathrm{ft} / \mathrm{sec}$

INITIAL REVERSE ROCK VEL $=15750.2 \mathrm{ft} / \mathrm{sec}$

ASSUMED OVERBURDEN VEL $=1000.0 \mathrm{ft} / \mathrm{sec}$

늘

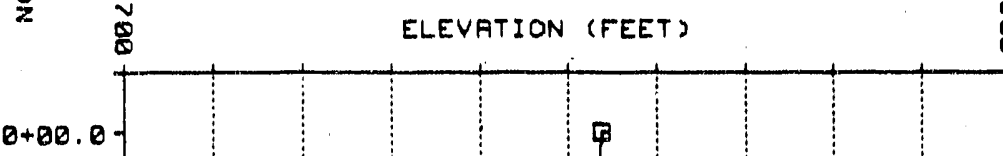

$0+90.0$

$1+18.8$

$1+30.0$

$1+50.8$

$1+70.0$

$1+90.0$

$2+10.0$

$2+30 \cdot 0$

$2+50.8$

$2+70.0$

$2+90.0$

$3+10.0$

$3+30.0-$

$3+50.0$

$3+70.0$

$3+90.0$

$4+10.0$

$4+3 B \cdot 0$

$4+50.0$

$4+70.0$

$4+90.0-$

$5+10.0$

$5+30.0$

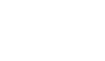

$5+95 \cdot 0$

甲

$+\infty$

$\phi$ 
APPENDIX A

Seismic Refraction Station Summaries for the Feasibility Study 


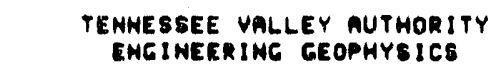

ORNL SWASA 6 LINE 2A-2E

SE ISMIC REFRACTION STATION SUMMARY

FEBRIJARY 12,198?

FORWARD SHOT POINT AT O+QO

REVERSE SHOT POINT AT $5+915$

FORHARD CALCULATED ROCK VELDCITY $=8663.9 \mathrm{rt} / \mathrm{seC}$

FORHARD ASSUMED ROCK VELOCITY

\section{$8,8,98 \mathrm{sec}$}

REVERSE CALCULATED ROCK VELOCITY - $15750.2 \mathrm{rl} / \mathrm{HEC}$

REVERSE ASSUMED ROCK VELOCITY. O. FI/SEC

DASED OH CALCULATED VELOCITIES THE ARITHMETIC AVERAGE VELOCITY $12207.0 \mathrm{CQ} / \mathrm{BEC}$

CALCULAYED ROCK VELOCITIES HERE USED TO CORRECT FOR NORMRL MOVEOUT.

RECORDINE PARAMETERS

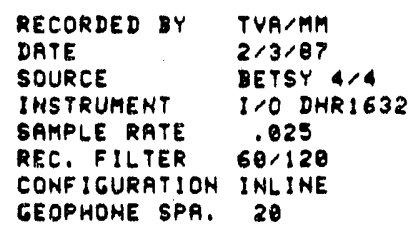

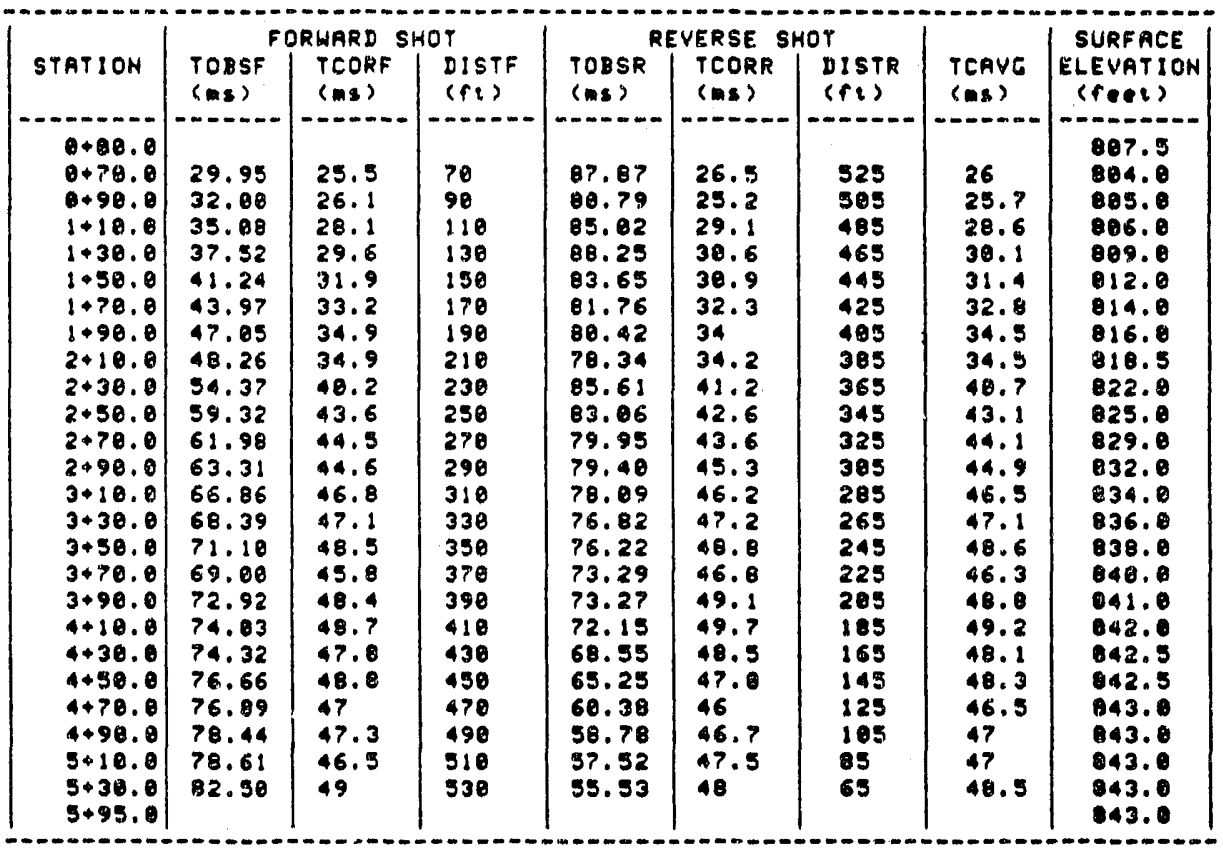

NOTE :

TOBSF - YHE FORHARD OBSERYED TIME

TCORF - THE FORWARD OBSERVED TIME CORRECTED FOR NORMAL MOVEOUT

- TOBSF - (DISTANCE FROM SHOT/FORHARD VELOCITY)

TOBSR - THE REVERSE OBSERVED TIME

TCORR = THE REVERSE OBSERYED TIME CORRECTED FOR NORMAL MOVEOUT

- TOBSR “ (DISTAMCE FROM SHOT/REVERSE VELOCITY) 


\section{TEHWEEEE WALLEY AUTHORITY \\ ENCSMEERIMG CEOPMYSICE \\ wont $10-15$ \\ SEISMIC REFRACTIOH STATION SUMMARY \\ FEBRUARY di, ISa?}

FORMARD SHOT POINY AT $0+00$

REVERSE SHOT POINT AT $6+00$

FORHARD CALCULATED ROCK VELOCITY 9110.1 PI/SEC

FORHARD ASSUMED ROCK VELOCITY - 0.0 reIseC

REVERSE CALCULATED ROCK VELOCITY 15669.6 risEC

REVERSE ASSLIMED RUCX VELOCITY $0.0 \mathrm{rL} / \mathrm{BEC}$

IASED ON CALCULATED VELOCITIES THE ARITHMETIE AYERACE VELOCITY $12389.8 \mathrm{fL} / \mathrm{seC}$

CALCULATED ROCK VELOCITIES HERE USED TO CORRECT FOR MORMAL MOYEOUT.

RECORDING PARAMETERS

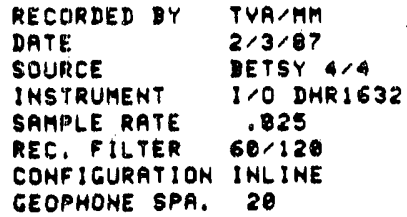

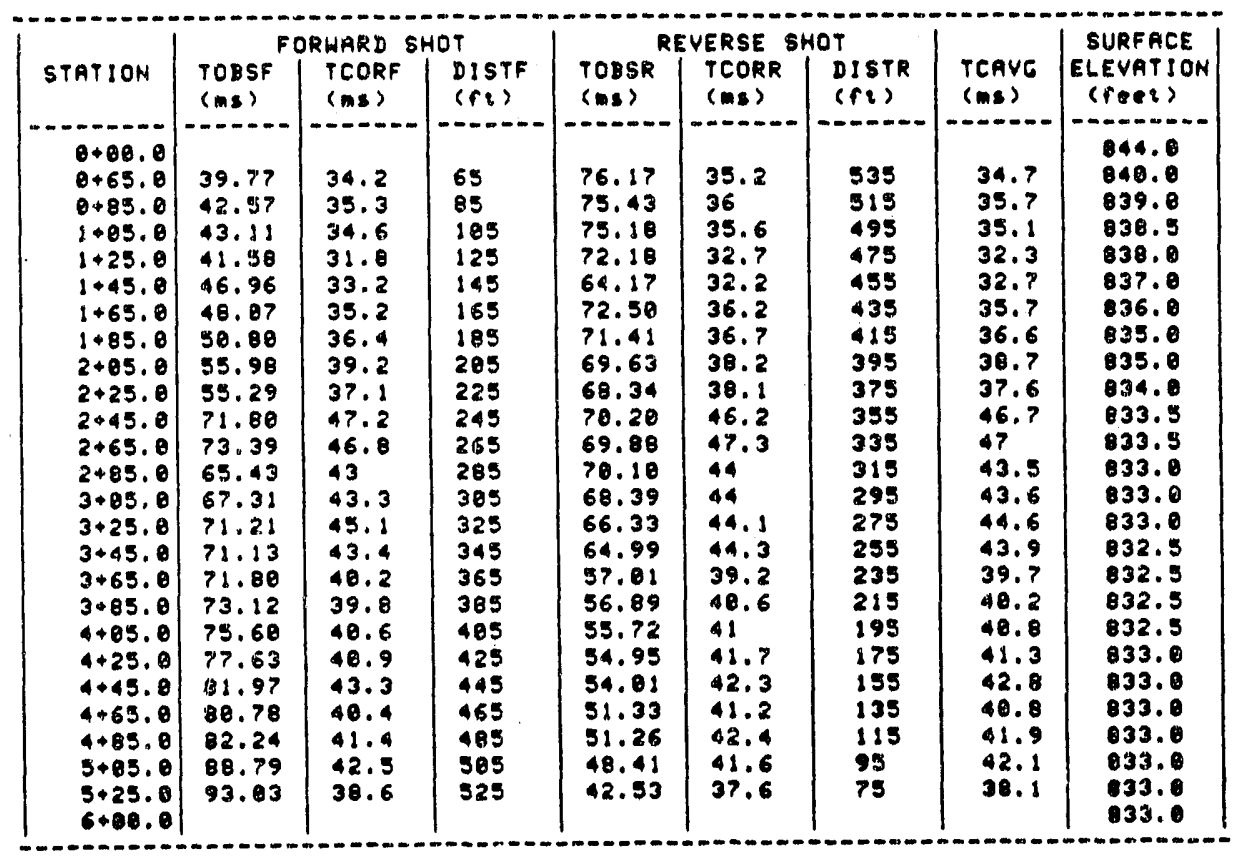

NOTE :

TOBSF - THE FORMARD ORSERVED TIME

TCORF THE FORHARD OQSERYED TIME CORRECTED FOR NORMAL MOVEOUY

- TOBSF - CDISTANCE FROM SHOT/FORHARD YELOCITY)

TODSR - THE REVERSE ODSERVED TIME

TCORR - THE REYERSE OBSERVED TIME CORRECTED FOR NORHAL MCIVEOUT - TOBSR - (DISTRNCE FROM SHOT/REVERSE VELOCITY) 


\section{INTERNAL DISTRIBUTION}

1. J. S. Baldwin

2. C. M. Beaudoin

3. R. B. Clapp

4. K. W. Cook

5. N. H. Cutshall

6-10. R. B. Dreier

11. C. S. Haase

12. F. J. Homan

13. D. D. Huff

14. L. D. Hyde

15. R. O. Kennard

16. H. L. King

17. J. T. Kitchings

18. S. Y. Lee

19. L. W. Long

20. L. E. McNeese

21. G. K. Moore

22. T. E. Myrick

\section{3-26.}

27. D. E. Reichle

28. P. S. Rohwer

29. T. H. Row

30. F. E. Sharples

31-35. R. J. Selfridge

36. D. K. Solomon

37. B. P. Spalding

38. L. E. Stratton

39. S. H. Stow

40. J. Switek

41. L. E. Toran

42. J. R. Trabalka

43. J. E. Van Cleve

44. L. D. Voorhees

45-47. ESD Library

48. Laboratory Records, RC

\section{EXTERNAL DISTRIBUTION}

49. J. K. Carmichael, U. S. Geological Survey, A413 Federal Building, U.

S. Courthouse, Nashville, TN 37302

50. P. M. Craig, ECE Inc., P.O. Box 22668, Knoxville TN 37933

51. R. A. Hopkins, TVA, Engineering Geology \& Seismology Section, 177 Liberty Building, Knoxville, TN 37902

52. J. Nemec, Bechtel National Inc., P.O. Box 350, Oak Ridge, TN 37831

53. D. A. Lietzke, Department of Plant and Soil Science, The University of Tennessee, Knoxville, TN 37916

54. C. J. Mankin, Director, Oklahoma Geological Survey, The University of Oklahoma, 830 Van Vleet Oval, Room 163, Norman, OK 73019

55. W. Stanley, MCI, P.O. Box 23010, Knoxville, TN 37922-1010

56. P. Tucci, U. S. Geological Survey, A413 Federal Building, U. S. Courthouse, Nashville, TN 37302

57. D. A. Webster, U. S. Geological Survey, 1013 N. Broadway, Knoxville, TN 37917

58. M. G. Wolman, The Johns Hopkins University, Department of Geography and Environmental Engineering, Baltimore, MD 21218

59. H. H. Zehner, U. S. Geological Survey, 1013 N. Broadway, Knoxville, TN 37917 'L'AN'L MANAGEK, ENEKGY RESEAKCH AND DE'VELLOPME'N'I', 60. U.S. DEPARTMENT OF ENERGY, DOE FIELD OFFICE, OAK RIDGE P.O. BOX 2001, OAK RIDGE, TN 37831-8600

61-62. OFFICE OF SCIENTIFIC AND TECHNICAL INFORMATION, P.O. BOX 62, OAK RIDGE, TENNESSEE 37831 

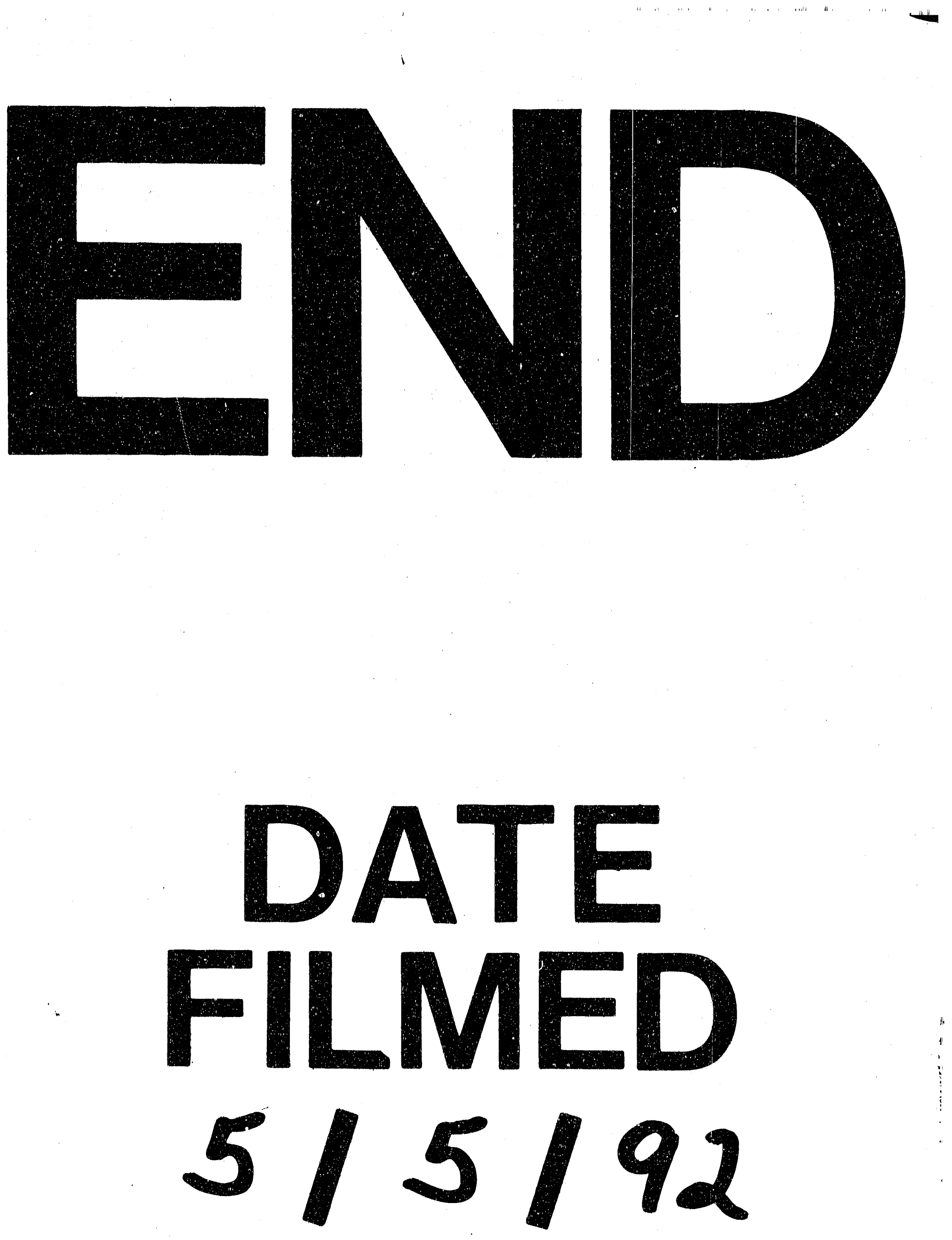
